\title{
Inovasi Pendampingan Bimbingan Belajar Anak Sekolah Dasar untuk Meningkatkan Motivasi Belajar
}

\author{
Suwandi $^{1}$, Widya Jati Lestari ${ }^{2 *}$, Ilwan Syafrinal ${ }^{3}$ \\ ${ }^{1,2}$ Program Studi Komputerisasi Akuntansi, Fakultas Teknologi Informasi, Universitas Catur Insan \\ Cendekia, Kota Cirebon, Indonesia \\ ${ }^{3}$ Program Studi Teknik Informatika, Fakultas Teknologi Informasi, Universitas Catur Insan Cendekia, \\ Kota Cirebon, Indonesia \\ Email: ${ }^{1}$ suwandi@cic.ac.id, ${ }^{2 *}$ widya.jatilestari@cic.ac.id, ${ }^{3}$ ilwan.syafrinal@cic.ac.id
}

\begin{abstract}
This community service activity in the form of tutoring during the COVID-19 pandemic is the concern and responsibility of lecturers and students (HIMAKA) of Cirebon City Catur Insan Cendekia University in the field of education. The purpose of this community service activity is to motivate activity participants and overcome the saturation level of elementary school students in the Kalijaga Village, Cirebon City, who for more than 1 year have been doing the online learning process at their respective homes. This activity was attended by elementary school students who are in the neighborhood around Baperkam $R W .12$ Kalijaga Village, Cirebon City. The method of implementing this service activity is a survey of activity needs, activity plans, implementation of tutoring activities and evaluation of activities. The results of this community service activity in the field of education show the enthusiasm, motivation and enthusiasm of elementary school students in participating in this tutoring activity. The consistency of the academic community in carrying out community service activities in the field of education needs to be maintained and even improved in order to support the tri dharma of higher education.
\end{abstract}

Keywords: Motivation, Guidance, Learning, Consistency.

\begin{abstract}
Abstrak
Kegiatan pengabdian kepada masyarakat berupa bimbingan belajar di masa pandemi covid-19 ini adalah merupakan kepedulian dan tanggung jawab dosen dan mahasiswa (HIMAKA) Univerisitas Catur Insan Cendekia Kota Cirebon di bidang pendidikan. Tujuan kegiatan pengabdian kepada masyarakat ini adalah untuk memberikan motivasi kepada peserta kegiatan dan mengatasi tingkat kejenuhan para murid Sekolah Dasar di lingkungan Kelurahan Kalijaga Kota Cirebon, yang selama 1 tahun lebih melakukan proses pembelajaran secara online di rumah masing-masing. Kegiatan ini diikuti oleh para murid Sekolah Dasar yang berada di lingkungan sekitar Baperkam RW.12 Kelurahan Kalijaga Kota Cirebon. Metode pelaksanan kegiatan pengabdian ini adalah survey kebutuhan kegiatan, rencana kegiatan, pelaksanaan kegiatan bimbingan belajar dan evaluasi kegiatan. Hasil kegiatan pengabdian kepada masyarakat di bidang pendidikan ini menunjukkan semangat, motivasi dan antusias para murid Sekolah Dasar dalam mengikuti kegiatan bimbingan belajar ini. Konsistensi civitas akademis dalam melakukan kegiatan pengabdian kepada masyarakat di bidang pendidikan perlu dipertahankan bahkan ditingkatkan dalam rangka menunjang tri dharma perguruan tinggi.
\end{abstract}

Kata Kunci: Motivasi, Bimbingan, Belajar, Konsistensi.

\section{A. PENDAHULUAN}

Menurut (Amalia \& Sa'adah, 2020), ada awal tahun 2020 pertama kali munculnya suatu varian virus baru bernama Corona. Penyakit yang dikenal dengan istilah COVID-19 ini, pertama kali menyerang Cina (Kota Wuhan), di bulan November 2019. Corona yg semula dipercaya virus biasa, ternyata prediksi tersebut salah, bahkan virus ini bisa membunuh insan sekaligus menyebar dengan sangat cepat. Pada saat ini disrupsi teknologi terjadi di dunia Pendidikan, pembelajaran tatap muka yang dilaksanakan 100 persen di sekolah, secara tiba-tiba mengalami perubahan yang sangat drastis. Dan, tak bisa dipungkiri di atas 50 persen pelajar dan mahasiswa berasal dari masyarakat berpenghasilan rendah dan menengah (Siahaan, 2020). 
Saat ini pendidikan ini mengalami masa krisis lantaran pandemi Covid-19. Tenaga Pengajar melakukan proses belajar mengajar dengan melakukan pembelajaran jarak jauh/pembelajaran daring. Untuk itu, dibutuhkan sinergitas antara siswa, orang tua, dan tenaga pengajar dalam melaksanakan pembelajaran tersebut, tenaga pengajar harus dapat berinovasi sehingga mengakibatkan pembelajaran tidak membosankan (Laksana et al., 2020).

Menteri Pendidikan \& Kebudayaan (Mendikbud) menerbitkan Surat Edaran Nomor 4 Tahun 2020 mengenai Pelaksanaan Pendidikan Dalam Masa Darurat Coronavirus Disease (Covid-19). Dalam edaran tersebut masih terdapat beberapa konsep mengenai belajar di rumah. Konsep tersebut merupakan pembelajaran pada jaringan (daring), dilaksanakan untuk memberikan pengalaman belajar yg bermakna bagi siswa, tanpa terbebani tuntutan menyelesaikan semua capaian kurikulum buat kenaikan kelas juga kelulusan. Masa pandemi Covid-19 ini mempunyai dampak yang cukup besar pada proses pembelajaran, antara lain: siswa yang merasa bosan dalam kegiatan belajarnya karena yang biasanya dilakukan secara tatap muka kini beralih ke pembelajaran online dan proses pembelajarannya dirasa kurang efektif. Kurangnya wawasan pembelajaran online dapat diatasi dengan dukungan belajar siswa, salah satunya adalah pendampingan pembelajaran. Pendampingan pembelajaran adalah upaya membantu individu atau kelompok dalam mengambil keputusan dan mengkoordinasikan serta memecahkan masalah pembelajaran melalui satu atau lebih fasilitator dengan keahlian disiplin ilmu tertentu (Pahmi et al., 2021).

Motivasi adalah dorongan yang dimiliki oleh setiap orang, termasuk siswa, dalam melakukan segala hal, dalam hal ini belajar. Motivasi belajar yang tinggi tercermin dari perilaku seseorang dalam mengejar proses belajar. Umumnya jika seseorang termotivasi untuk melakukan aktivitas tersebut, maka orang tersebut merasa senang dan mencoba untuk mempertahankan rasa senangya ini. Demikian pula, jika seseorang termotivasi untuk belajar, maka perlu meningkatkan perilaku yang baik dalam proses pembelajaran tersebut (Imtihani et al., 2021).

Permasalahan yang muncul saat ini adalah masih banyak siswa yang mengalami kesulitan untuk belajar mandiri. Salah satu efek yang jelas adalah ketidakmampuan belajar yang dialami siswa dalam proses pendidikan dan pembelajaran di rumah. Siswa merasa tertekan dalam pembelajaran jarak jauh, terutama bila dikombinasikan dengan sarana dan prasarana rumah yang tidak memadai, karena mereka merasa terpaksa untuk belajar. Kendala lain adalah sulitnya orang tua memahami materi, merangsang semangat dan motivasi belajar anaknya, memisahkan waktu antara pekerjaan orang tua dan pengasuhan anak, pemahaman orang tua dalam menggunakan gadget, terbatasnya jangkauan internet. Beberapa kendala tersebut sangat menghambat proses belajar siswa ketika dilakukan secara daring (Utomo et al., 2021).

Pembelajaran online/online membuat siswa lebih pasif, tidak mampu menyampaikan aspirasi dan pemikirannya, membuat kegiatan belajar menjadi kurang menyenangkan bahkan membosankan. Kejenuhan belajar adalah kondisi emosional yang dialami siswa, dan tuntutan akademik yang meningkat menyebabkan kebosanan dan rasa tidak enak, yang mengakibatkan siswa ragu-ragu untuk mengikuti kegiatan pembelajaran dan dapat menghambat pembelajaran. Pembelajaran membosankan yang dialami siswa dapat mengakibatkan hasil belajar yang kurang baik, karena siswa tersebut tidak dapat berpikir dengan baik selama kegiatan pembelajaran. Selain itu, kebosanan belajar juga menyebabkan siswa kurang efektif dalam mengikuti kegiatan pembelajaran (Wangge et al., 2021).

Kejenuhan pembelajaran secara daring juga dirasakan para murid Sekolah Dasar di Wilayah Kecamatan Harjamukti Kotamadya Cirebon. Hampir satu tahun lebih, mereka tidak dapat melakukan proses belajar di sekolahnya masing-masing akibat masa pendemi Covid-19. Atas dasar hal tersebut, HIMAKA (Himpunan Mahasiswa Komputerisasi Akuntansi) Universitas Catur Insan Cendekia Cirebon dan para dosen dari Prodi tersebut berniat untuk melakukan kegiatan pengabdian kepada masyarakat. Kegiatan yang dilakukan berupa pendampingan belajar di luar sekolah dengan tujuan mengatasi kejenuhan para murid Sekolah Dasar di Wilayah Kecmatan Harjamukti Kota Cirebon.

Kegiatan pengabdian kepada masyarakat ini dilakukan dengan melakukan kegiatan belajar di ruangan aula Baperkam (Balai Permusyawaratan Kampung) di Wilayah sekitar Kecamatan Harjamukti. Awal kegiatan dimulai dengan menginventarisir para murid Sekolah Dasar yang berminat untuk mengikuti kegiatan tersebut, setelah mendapatkan persetujuan dari orang tua murid. Tahap selanjutnya, setelah mendapatkan data calon peserta murid, dilakukan penyusunan jadwal pembelajaran selama 1 bulan (4 x pertemuan). Tujuan kegiatan ini adalah untuk memotivasi para murid Sekolah Dasar di lingkungan Kecamatan Harjamukti Kota Cirebon agar tetap bersemangat dalam belajar. 


\section{B. PELAKSANAAN DAN METODE}

Lokasi pelaksanaan kegiatan pengabdian kepada masyarakat ini adalah di aula Balai Permusyawaratan Kampung (Baperkam) RW.12 Kelurahan Kalijaga - Kecamatan Harjamukti Kota Cirebon. Adapun waktu pelaksanaan kegiatan ini adalah sebagai berikut :

Tabel 1. Waktu Pelaksanaan Kegiatan Pendampingan Bimbingan Belajar

\begin{tabular}{|c|c|c|c|}
\hline No. & Hari / Tanggal & Materi Belajar & Tim Pengajar \\
\hline 1 & Sabtu, 16 Januari 2021 & Bahasa Inggris & $\begin{array}{l}\text { Mahasiswa: } \\
\text { Nais Rahmawati } \\
\text { Dewi Nandhayani } \\
\text { Nizar Farhan } \\
\text { Dosen : } \\
\text { Widya Jati L. , M.M. }\end{array}$ \\
\hline 2 & Sabtu, 23 Januari 2021 & $\begin{array}{l}\text { Matematika dan } \\
\text { Menggambar }\end{array}$ & $\begin{array}{l}\text { Mahasiswa : } \\
\text { Niar Apriyani } \\
\text { Renyta Oktaviani } \\
\text { Arin Aristiani } \\
\\
\text { Dosen : } \\
\text { Suwandi, S.E., M.M. }\end{array}$ \\
\hline 3. & Sabtu, 30 Januari 2021 & $\begin{array}{l}\text { Bahasa Indonesia } \\
\text { dan Pancasila }\end{array}$ & $\begin{array}{l}\text { Mahasiswa: } \\
\text { Adjustina Diva } \\
\text { Belinda Novelia } \\
\text { Nouval Yudho } \\
\\
\text { Dosen: } \\
\text { Ilwan Syafrinal, M.Kom }\end{array}$ \\
\hline 4. & Sabtu, 6 Februari 2021 & $\begin{array}{l}\text { Game dan } \\
\text { Motivasi }\end{array}$ & $\begin{array}{l}\text { Mahasiswa : } \\
\text { Nur Fanisa } \\
\text { Tria Restu } \\
\text { Nahniatul } \\
\text { M. Risky Setiawan } \\
\\
\text { Tim Dosen : } \\
\text { Suwandi, S.E., M.M. } \\
\text { Ilwan Syafrinal, M.Kom. }\end{array}$ \\
\hline
\end{tabular}

Tabel-1 adalah rencana kegiatan bimbingan belajar selama 1 bulan atau 4 x pertemuan. Adapun pelaksanaan kegiatan dilakukan pada Hari Sabtu, atas kesepakatan dengan pihak orang tua murid dan Ketua RW setempat. Beberapa mata pelajaran yang akan diajarkan saat melakukan bimbingan belajar tersebut antara lain Bahasa Inggris, menggambar, Bahasa Indonesia, Pancasila, Game dan motivasi. 


\section{METODE}
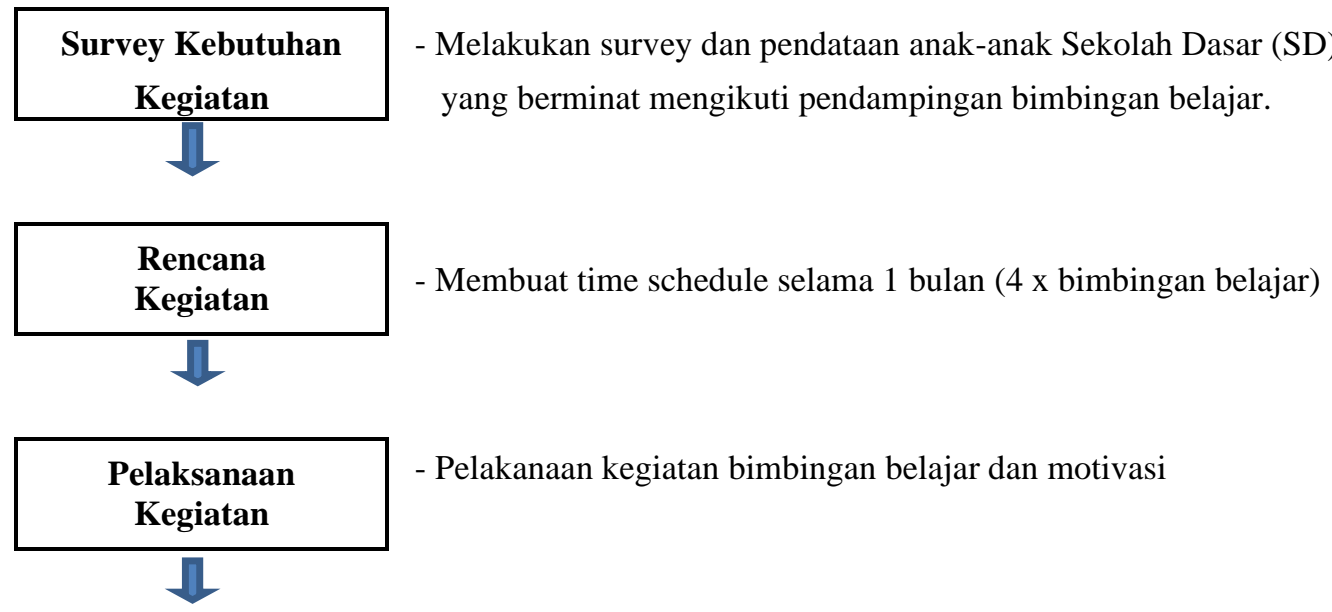

- Pelakanaan kegiatan bimbingan belajar dan motivasi

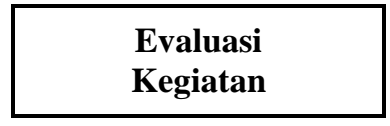

- Evaluasi hasil kegiatan untuk perbaikan kegiatan bimbingan

belajar ke depannya.

Gambar-1 Metode Pelaksanaan Kegiatan

Gambar-1 adalah metode yang digunakan dalam kegiatan pengabdian kepada masyarakat berupa bimbingan belajar anak-anak Sekolah Dasar, saat masa pandemi covid-19.

Kegiatan dimulai dengan (1)melakukan survey kebutuhan kegiatan, dimana tim dosen dan mahasiswa Universitas Catur Insan Cendekia (UCIC) Prodi Komputerisasi Akuntansi mendata anak-anak Sekolah Dasar (SD) yang memiliki keinginan untuk mengikuti kegiatan ini atas persetujuan orang tua. (2)Selanjutnya tim melakukan pembuatan jadwal rencana kegiatan, yang akan dilakukan yaitu selama 4x pertemuan dalam 1 bulan, disertai nama petugas (dosen dan mahasiswa). (3)Tahap berikutnya adalah pelaksanaan kegiatan pendampingan bimbingan belajar di aula Baperkam RW.012 Kelurahan Kalijaga Kota Cirebon. (4)Adapun tahap terakhir adalah evaluasi kegiatan atas kegiatan pengabadian kepada masyarakat yang telah dilakukan.

\section{HASIL DAN PEMBAHASAN}

Hasil yang diperoleh dari kegiatan pengabdian kepada masyarakat ini adalah berupa pendampingan bimbingan belajar saat masa pandemi covid-19, yang dilaksanakan di Aula Baperkam RW.12 Kelurahan Kalijaga Kota Cirebon. Kegiatan pengabdian ini merupakan kreativitas Himpunan Mahasiswa Komputerisasi Akuntansi (HIMAKA) dan Dosen Universitas Catur Insan Cendekia dalam rangka menjalankan tri dharma perguruan tinggi.

Pelaksanaan kegiatan bimbingan belajar ini dilakuksn selama 4x dalam 1 bulan, dengan tahapan sebagai berikut : (1)pembagian alat tulis secara gratis, yang bertujuan untuk meningkatkan antusiasme anak-anak dalam kegiatan bimbingan belajar ini. (2)pemberian motivasi belajar berupa permainan (games) kelompok dan cerita-cerita motivasi belajar walaupun dalam masa pandemi, (3)pemberian materi bimbingan belajar sesuai jadwal yaitu: Bahasa Inggris, Matematika dan Menggambar, Bahasa Indonesia dan Pancasila. (4)Tanya jawab dan kuis (berhadiah), (5)pembagian hadiah bagi siswa yang memenangkan kuis, dan berani menjawab pertanyaan dengan baik dan benar.

Beberapa faktor yang mendorong dapat berjalannya program pengabdian ini adalah antusias para peserta bimbingan belajar, dukungan orang tua peserta dan support dari Ketua RW setempat dalam pemberian ijin aula Baperkam. Sementara itu, kegiatan pengabdian ini tidak terdapat faktor penghambat, karena acara ini secara keseluruhan dapat berjalan sesuai rencana. Program ini dilaksanakan dengan tetap memperhatikan protokol kesehatan, dimana seluruh peserta dan tim pengajar wajib menggunakan masker. 

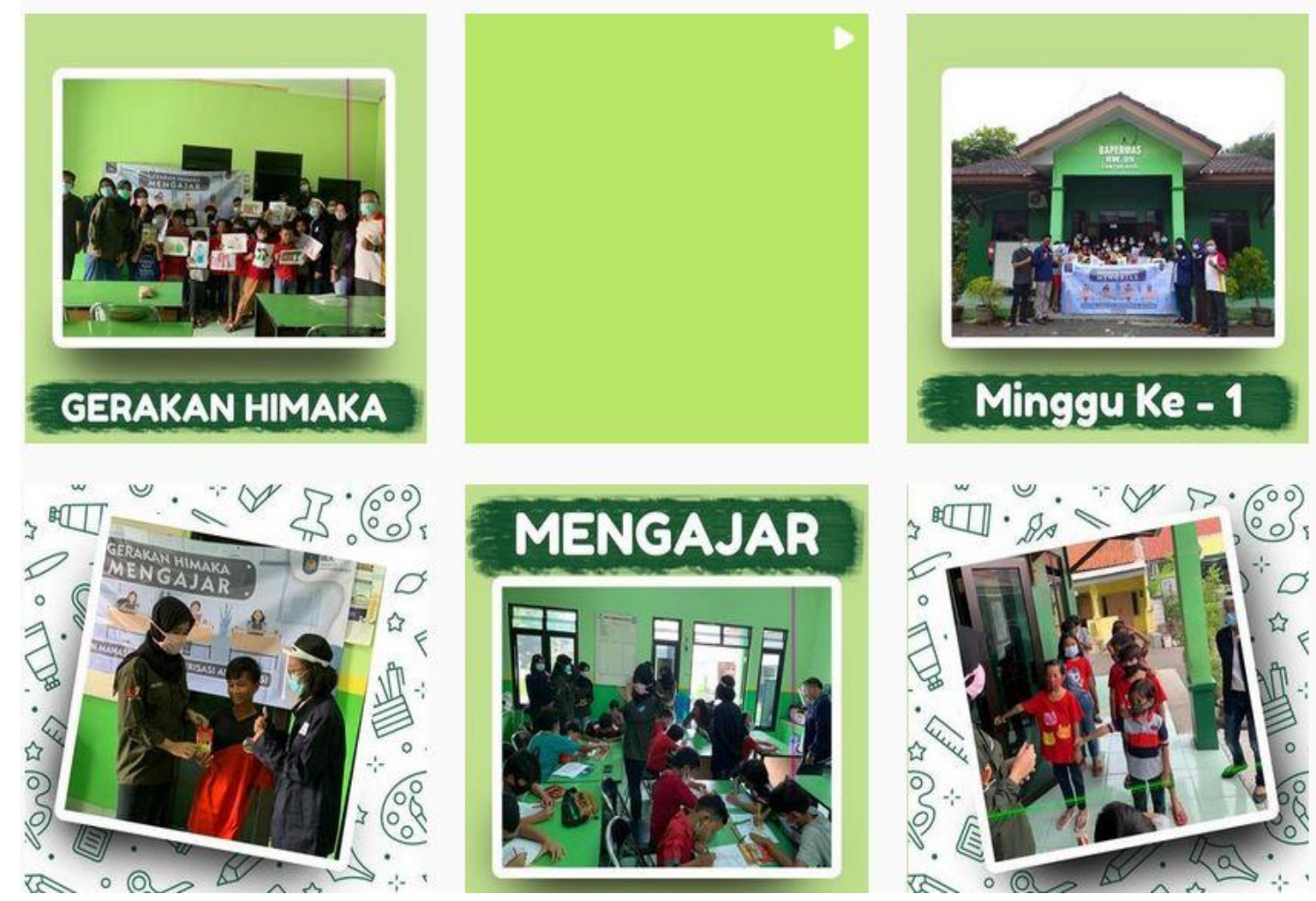

Gambar-1 Dokumentasi Kegiatan Pengabdan Minggu ke-1 dan ke-2

\section{Keterangan Gambar-1 :}

Dalam gambar-1 di atas terdapat 5 kegiatan (foto atas dan foto bawah), dengan rincian sebagai berikut :

- Foto atas (kiri), adalah kegiatan saat materi pembelajaran menggambar, dan dilakukan foto bersama peserta bimbingan belajar, mahasiswa dan dosen.

- Foto atas (kanan), sesi foto bersama setelah selesai acara bimbingan belajar.

- Foto Bawah (kiri), pemberian reward kepada salah satu siswa peserta bimbingan belajar yang berhasil menjawab pertanyaan.

- Foto Bawah (tengah), adalah kegiatan bimbingan belajar.

- Foto Bawah (kanan), adalah kegiatan berbaris di depan ruangan (sebelum acara bimbingan belajar dimulai).

Kegiatan bimbingan belajar di masa pandemi di Minggu ke-1 dan Minggu ke-2 ini dilakukan dengan memberikan materi pembelajaran antara lain:

Minggu ke-1

Bahasa Inggris, materi yang diberikan antara lain : Alphabet dan Numbers

Minggu ke-2

Materi tentang Matematika dan Menggambar 


\section{The Alphabet Song}

\begin{tabular}{|c|c|c|c|c|c|c|c|c|c|}
\hline A & B & C & D & E & F & G & H & I & J \\
\hline éi & bi & si & di & $i$ & Éf & Ji & éic & ay & jéy \\
\hline
\end{tabular}

\begin{tabular}{|c|c|c|c|c|c|c|c|c|c|}
\hline $\mathbf{K}$ & $\mathbf{L}$ & $\mathbf{M}$ & $\mathbf{N}$ & $\mathbf{O}$ & $\mathbf{P}$ & $\mathbf{Q}$ & $\mathbf{R}$ & $\mathbf{S}$ & $\mathbf{T}$ \\
\hline kéy & él & ém & Én & $\circ$ & $\mathrm{Pi}$ & Kiu & ar & és & ti \\
\hline
\end{tabular}

\begin{tabular}{|c|c|c|c|c|c|}
\hline$U$ & V & W & X & Y & Z \\
\hline yu & vi & Dabelyu & Éks & Way & $z i$ \\
\hline
\end{tabular}

Gambar-2 Materi Alphabet - Minggu ke-1

\section{A.Let's count 1 to 1.000 .000}

\begin{tabular}{|c|c|c|c|c|}
\hline$\frac{}{\text { One }}$ & $\frac{2}{\text { Two }}$ & Three & $\begin{array}{l}\text { Four } \\
\text { Fon }\end{array}$ & Five \\
\hline Six & $\begin{array}{c}\text { 담재 } \\
\text { Seven }\end{array}$ & Eight & $\begin{array}{c}\text { Nine } \\
\text { Ning }\end{array}$ & $\frac{90}{\text { Ten }}$ \\
\hline $\begin{array}{l}11 \\
\text { Eleven }\end{array}$ & $\begin{array}{l}12 \\
\text { Twelve }\end{array}$ & $\begin{array}{c}13 \\
\text { Thirteen }\end{array}$ & $\begin{array}{c}14 \\
\text { Fourteen }\end{array}$ & $\begin{array}{c}15 \\
\text { Fifteen }\end{array}$ \\
\hline $\begin{array}{c}16 \\
\text { Sixteen }\end{array}$ & $\begin{array}{c}17 \\
\text { Seventeen }\end{array}$ & $\begin{array}{c}18 \\
\text { Eighteen }\end{array}$ & $\begin{array}{c}19 \\
\text { Nineteen }\end{array}$ & $\begin{array}{l}20 \\
\text { Twenty }\end{array}$ \\
\hline $\begin{array}{l}30 \\
\text { Thirty }\end{array}$ & $\begin{array}{l}40 \\
\text { Forty }\end{array}$ & Fifty & $\begin{array}{l}60 \\
\text { Sixty }\end{array}$ & $\begin{array}{l}\text { (1) } \\
\text { Seventy }\end{array}$ \\
\hline Eighty & Ninety & $\begin{array}{c}100 \\
\text { One hundred }\end{array}$ & $\begin{array}{c}1000 \\
\text { One thousand }\end{array}$ & $\begin{array}{c}1.000 .000 \\
\text { One million }\end{array}$ \\
\hline
\end{tabular}

Gambar-3 Materi Numbers - Minggu ke-1

Sementara itu, materi bimbingan belajar yang diberikan pada Minggu ke-3 dan Minggu ke-4 adalah sebagai berikut :

Minggu ke-3 : Bahasa Indonesia dan Pancasila 


\section{GERAKAN HIMAKA}
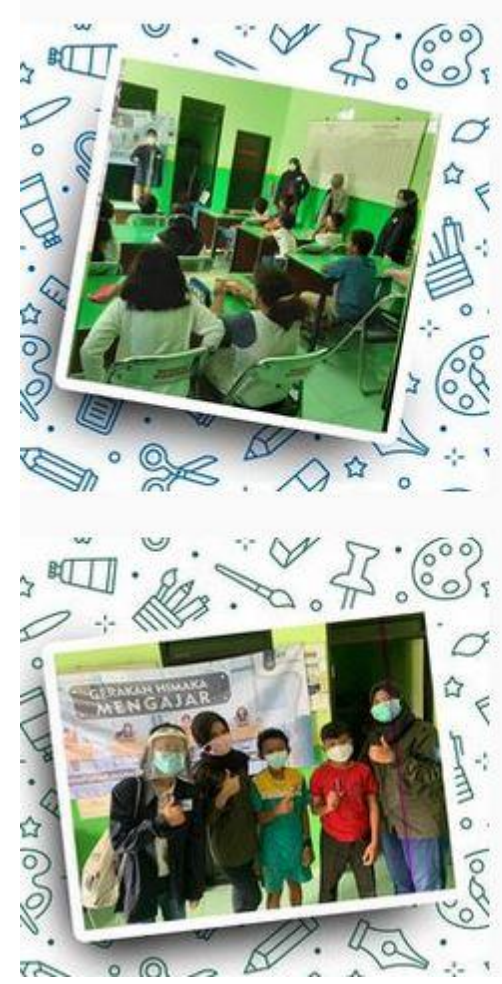
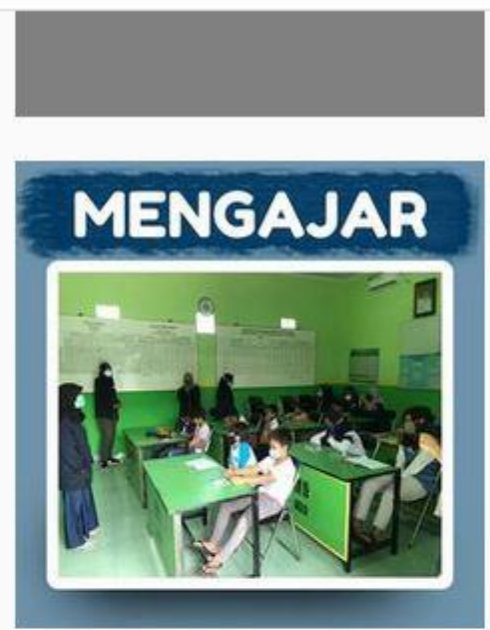

Minggu Ke - 2

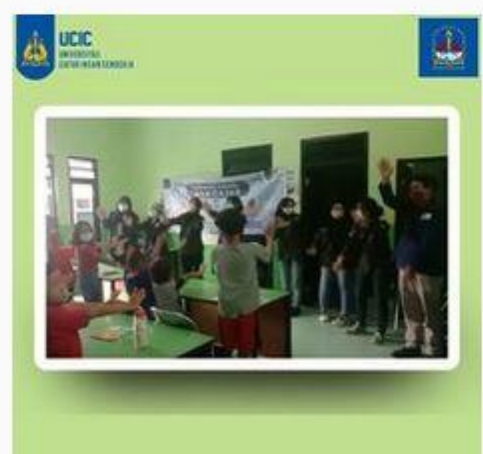

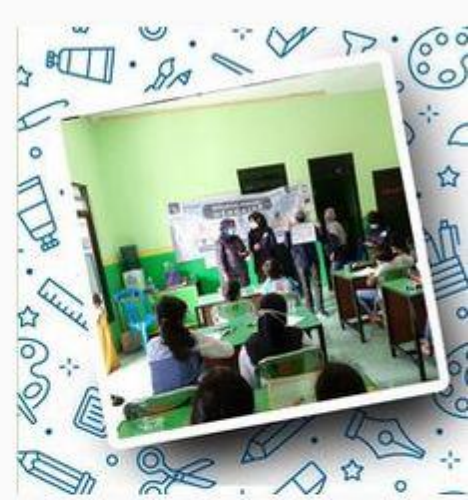

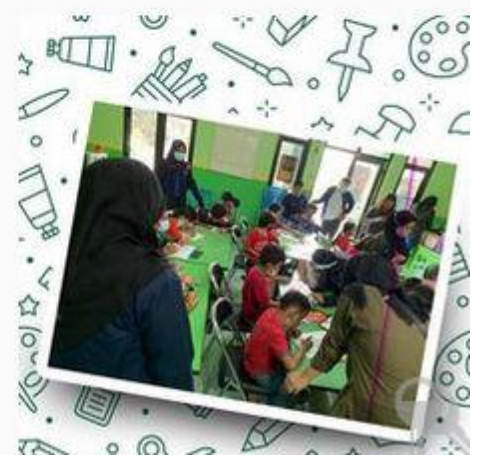

Gambar-4 Dokumentasi Kegiatan Pengabdan Minggu ke-3 dan ke-4

\section{Keterangan Gambar-4 :}

Dalam gambar-4 di atas terdapat 6 aktivitas (foto atas dan foto bawah), dengan rincian sebagai berikut :

- Foto atas, adalah kegiatan saat materi pembelajaran Minggu ke-3, yaitu Bahasa Indonesia dan Pancasila.

- Foto Bawah, adalah kegiatan saat materi pembelajaran Minggu ke-4, yaitu games dan motivasi.

\section{PENUTUP}

\section{Simpulan}

Pelaksanaan kegiatan pengabdian kepada masyarakat berupa bimbingan belajar kepada murid SD di lingkungan Kelurahan Kalijaga Kota Cirebon ini dapat berjalan sesuai harapan, dengan menggunakan protokol kesehatan. Permasalahan tingkat kejenuhan yang dihadapi saat pembelajaran melalui daring dapat terobati dengan adanya bimbingan belajar, mereka dapat berkumpul kembali setelah 1 tahun lebih melakukan pembelajaran di rumah masing-masing.

Adapun acara pengabdian tersebut dapat terlaksana melalui 5 tahapan, yaitu : (1)Proses awal dengan memberikan alat tulis secara gratis, (2)permainan (games) edukasi secara kelompok dan pemberian cerita-cerita motivasi belajar, (3)penyampaian materi bimbingan belajar sesuai jadwal, yaitu: Bahasa Inggris, Matematika dan Menggambar, Bahasa Indonesia dan Pancasila. (4)Tanya jawab dan kuis (berhadiah), (5)pemberian hadiah di setiap minggu kepada siswa yang aktif dan dapat menjawab pertanyaan .

Beberapa faktor pendukung dalam kegiatan bimbingan belajar ini antara lain : semangat dan antusias para murid Sekolah Dasar yang mengikuti bimbingan belajar, dukungan dari orang tua peserta dan support dari Ketua RW setempat dalam pemberian ijin aula Baperkam. Sementara itu, kegiatan 
pengabdian ini tidak terdapat faktor penghambat, karena acara ini secara keseluruhan dapat berjalan sesuai rencana.

\section{Saran}

Agar kegiatan pengabdian ini ke depannya lebih baik lagi, dibutuhkan konsistensi dari kalangan civitas akademis untuk terus berkreasi dalam melakukan kegiatan pengabdian serupa. Dengan demikian terciptanya sinergi antara peserta didik, orang tua murid dan civitas akademik,

\section{E. DAFTAR PUSTAKA}

Amalia, A., \& Sa'adah, N. (2021). Dampak Wabah Covid-19 Terhadap Kegiatan Belajar Mengajar Di Indonesia. Jurnal Psikologi, 13(2), 214-225.

Link : https://ejournal.gunadarma.ac.id/index.php/psiko/article/view/3572

Siahaan, M. (2020). Dampak pandemi Covid-19 terhadap dunia pendidikan. Dampak Pandemi Covid-19 Terhadap Dunia Pendidikan, 20(2).

Link : http://repository.ubharajaya.ac.id/4842/2/Jurnal\%20PANDEMIC\%20MATDIO\%20S.pdf

Imtihani, A., Affandi, L. H., \& Tahir, M. (2021). MOTIVASI BELAJAR SISWA SEKOLAH DASAR PADA MASA PANDEMI COVID 19 DI KECAMATAN KAYANGAN. Jurnal Kependidikan, 6(1), 13-20.

Link : https://e-journallppmunsa.ac.id/index.php/kependidikan/article/view/385/361

Pahmi, S., Suciani, A., Yulianti, R., Putri, C. S., \& Sagita, T. (2021). Pendampingan Belajar Di Masa Pandemi Covid-19 Untuk Meningkatkan Motivasi Dan Minat Belajar Siswa Di Desa Gegerbitung. Jurnal Komunitas: Jurnal Pengabdian Kepada Masyarakat, 4(1), 55-59.

Link : https://ojs.stiami.ac.id/index.php/jks/article/view/1635

Utomo, K. D., Soegeng, A. Y., Purnamasari, I., \& Amaruddin, H. (2021). Pemecahan Masalah Kesulitan Belajar Siswa pada Masa Pandemi Covid-19. Mimbar PGSD Undiksha, 9(1), 1-9.

Link : https://ejournal.undiksha.ac.id/index.php/JJPGSD/article/viewFile/29923/18016

Wangge, M. Y., Santoso, A. P., Kartika, V., \& Febriani, U. F. (2021). Strategi Guru Dalam Mengatasi Kejenuhan Belajar Daring Pada Siswa SMAN 4 Semarang Selama Masa Pandemi. JURNAL PENELITIAN PENDIDIKAN, PSIKOLOGI DAN KESEHATAN (J-P3K), 2(2), 135-141.

Link : https://jurnalp3k.com/index.php/J-P3K/article/view/109

Laksana, D. N. L., Kaka, P. W., Muga, W., \& Wero, L. (2020). Pendampingan belajar siswa di luar kelas dalam masa pandemi covid-19 sebagai implementasi matakuliah model pembelajaran inovatif. Jurnal Abdimas Ilmiah Citra Bakti, 1(2), 97-104.

Link : https://jurnalilmiahcitrabakti.ac.id/jil/index.php/jailcb/article/view/102 